\title{
Life-threatening hypophosphataemia in a cirrhotic patient with jaundice
}

\author{
Elisavet Moutzouri, Evangelos N. Liberopoulos, Moses Elisaf
}

Department of Internal Medicine, Medical School, University of Ioannina, Ioannina, Greece

Submitted: 12 July 2010

Accepted: 21 September 2010

Arch Med Sci 2011; 7, 4: 736-739

DOI: $10.5114 / a o m s .2011 .24148$

Copyright ( 2011 Termedia \& Banach

\section{Abstract}

We report the case of a 51-year-old patient with a history of liver cirrhosis, who presented with jaundice (total bilirubin $50 \mathrm{mg} / \mathrm{dl}$ [ $855 \mathrm{\mu mol} / \mathrm{l}]$, direct bilirubin $20 \mathrm{mg} / \mathrm{dl}[342 \mu \mathrm{mol} / \mathrm{l}]$ ) and life-threatening hypophosphataemia (serum phosphate $0.5 \mathrm{mg} / \mathrm{dl}[0.16 \mathrm{mmol} / \mathrm{l}]$ ), accompanied by inappropriate phosphaturia. The patient also manifested hypouricaemia (serum uric acid $1.7 \mathrm{mg} / \mathrm{dl}$ $[101 \mu \mathrm{mol} / \mathrm{l}]$ ) with renal uric acid wasting and renal glycosuria. This generalized proximal tubular defect may occasionally be seen in deeply jaundiced patients. Therefore, serum phosphate levels should be closely monitored in these patients.

Key words: hypophosphataemia, jaundice, cirrhosis, hepatitis.

\section{Introduction}

Normal serum phosphate ranges from $2.5 \mathrm{mg} / \mathrm{dl}$ to $4.5 \mathrm{mg} / \mathrm{dl}$ (0.80$1.45 \mathrm{mmol} / \mathrm{l})$. Hypophosphataemia is classified as moderate when serum phosphate is $1.0-2.5 \mathrm{mg} / \mathrm{dl}(0.32-0.80 \mathrm{mmol} / \mathrm{l})$ and severe when $<1.0 \mathrm{mg} / \mathrm{dl}$ ( $<0.32 \mathrm{mmol} / \mathrm{l})$. Hypophosphataemia is observed in $0.25-2.15 \%$ of hospital admissions, while severe hypophosphataemia affects $0.43 \%$ of hospitalized patients [1].

Maintaining normal phosphate concentrations is essential for optimal cellular function. Hypophosphataemia, especially when it is severe, may result in serious complications, such as rhabdomyolysis, haemolysis, and respiratory and cardiac failure. Clinical manifestations are usually encountered when serum phosphate concentration falls below $1 \mathrm{mg} / \mathrm{dl}$ (0.32 mmol/l) [1].

Decreased uric acid levels have been occasionally described in jaundiced patients [2]. However, jaundice may also lead to a more generalized proximal tubular dysfunction mimicking Fanconi's syndrome [3].

Herein we describe the case of a jaundiced patient with liver cirrhosis who developed life-threatening hypophosphataemia with inappropriate phosphaturia accompanied by hypouricaemia and glycosuria mimicking Fanconi's syndrome. The patient gave informed consent for publishing his case in the medical literature.

\section{Case report}

A 51-year-old man was admitted to our hospital because of abdominal distention and jaundice of recent onset. He had been diagnosed with

\author{
Corresponding author: \\ Prof. Moses Elisaf MD, FASA, \\ FRSH \\ Department of Internal \\ Medicine \\ School of Medicine \\ University of Ioannina \\ 45110 loannina, Greece \\ Phone: +302651007509 \\ Fax: +302651007016 \\ E-mail: egepi@cc.uoi.gr
}


chronic hepatitis B virus (HBV) infection and cirrhosis 5 years ago. He was under treatment with lamivudine $100 \mathrm{mg} /$ day, amiloride $2.5 \mathrm{mg} /$ day, furosemide $20 \mathrm{mg} /$ day and lactulose for 1 year. Until then his cirrhosis had been well compensated. The patient denies alcohol abuse in the past or currently.

On admission, his blood pressure (BP) was $120 / 75 \mathrm{mmHg}$, pulse rate $60 / \mathrm{min}$ and body temperature $36^{\circ} \mathrm{C}$. He had 16 breaths per minute and an oxygen saturation of $95 \%$ while breathing ambient air. The patient was conscious and well oriented in time and place with no flapping tremor. Icteric sclerae were noticed. Several spider angiomas were present on the chest and abdomen. The abdomen was distended and dilated veins were present on the surface (caput medusae).

Abdominal ultrasound showed the presence of ascites and a small irregular liver (without evidence of hepatocellular carcinoma). Colour flow Doppler ultrasonography revealed thrombus partially occluding the portal vein lumen. Splenomegaly was also present. Echocardiography revealed an ejection fraction of $60 \%$ with no signs of heart failure.

Peripheral blood count revealed moderate anaemia with thrombocytopenia. Arterial blood gas analysis showed $\mathrm{pH} 7.46, \mathrm{pCO}_{2} 38 \mathrm{mmHg}, \mathrm{pO}_{2}$ $71 \mathrm{mmHg}$ and $\mathrm{HCO}_{3}{ }^{-} 26.4 \mathrm{mmol} /$, suggesting mixed respiratory and metabolic alkalosis. Laboratory investigation revealed severe cholestasis (total bilirubin $50 \mathrm{mg} / \mathrm{dl}$ [855 $\mathrm{mmol} / \mathrm{l}]$, direct bilirubin $20 \mathrm{mg} / \mathrm{dl}[342 \mu \mathrm{mol} / \mathrm{l}])$ (Table I). Serum phosphate concentration was $0.5 \mathrm{mg} / \mathrm{dl}(0.16 \mathrm{mmol} / \mathrm{l})$, while fractional excretion of phosphate $\left(\mathrm{FEPO}_{4}{ }^{3-}\right)$ in urine was $400 \%$ (normal value $<20 \%$ ). There was no evidence of hypophosphataemia-related complications such as rhabdomyolysis, haemolysis, respiratory or cardiac failure. Rhabdomyolysis is a rare manifestation of severe hypophosphataemia [1]. Close monitoring for muscle-related symptoms as well as daily measurement of creatinine kinase levels are essential. Furthermore, hypophosphataemia may affect the cardiac muscle and lead to cardiomyopathy. In addition to a normal echocardiograph, creatinine kinase and troponin I levels were normal (Table I). Serum calcium, magnesium, sodium and potassium concentrations were within normal limits (Table I). The patient also manifested hypouricaemia (serum uric acid $1.7 \mathrm{mg} / \mathrm{dl}[101 \mu \mathrm{mol} / \mathrm{l}])$ with renal uric acid wasting (Table I). Of note, glycosuria was noted in a spot urine specimen. Urine $\beta_{2}$ microglobulin was markedly increased $(20 \mathrm{mg} / \mathrm{l}$ [normal value $<0.3 \mathrm{mg} / \mathrm{l}$ ]). Volume of 24-h diuresis ranged from $1200 \mathrm{ml}$ to $1500 \mathrm{ml}$ during his hospital stay.

Serum protein electrophoresis revealed polyclonal gammopathy, while both serum ceruloplasmin and ferritin were within normal limits. There was no history of heavy metal exposure.
Table I. Clinical and laboratory test results on admission

\begin{tabular}{|c|c|c|}
\hline Parameters & Results & $\begin{array}{c}\text { Normal limits } \\
\text { (conventional units) }\end{array}$ \\
\hline $\mathrm{BMI}\left[\mathrm{kg} / \mathrm{m}^{2}\right]$ & 17 & $18.5-24.9$ \\
\hline $\begin{array}{l}\text { TBIL }[\mathrm{mg} / \mathrm{dl}] \\
{[\mu \mathrm{mol} / \mathrm{l}]}\end{array}$ & $\begin{array}{c}50 \\
(855)\end{array}$ & $0.2-1.4$ \\
\hline $\begin{array}{l}\mathrm{DBIL}[\mathrm{mg} / \mathrm{dl}] \\
{[\mu \mathrm{mol} / \mathrm{l}]}\end{array}$ & $\begin{array}{c}20 \\
(342)\end{array}$ & $0.0-0.4$ \\
\hline $\begin{array}{l}\text { Cre }[\mathrm{mg} / \mathrm{dl}] \\
{[\mu \mathrm{mol} / \mathrm{l}]}\end{array}$ & $\begin{array}{l}1.2 \\
(92)\end{array}$ & $0.7-1.3$ \\
\hline BUN [mg/dl] & 38 & $8-23$ \\
\hline $\begin{array}{l}\text { Albumin }[\mathrm{g} / \mathrm{dl}] \\
{[\mathrm{g} / \mathrm{l}]}\end{array}$ & $\begin{array}{l}3.6 \\
(36)\end{array}$ & $3.4-5.0$ \\
\hline $\mathrm{K}^{+}[\mathrm{mEq} / \mathrm{ll}]$ & 3.89 & $3.5-5.3$ \\
\hline $\mathrm{Na}^{+}[\mathrm{mEq} / \mathrm{l}]$ & 143 & $135-153$ \\
\hline $\begin{array}{l}\mathrm{Ca}[\mathrm{mg} / \mathrm{dl}] \\
{[\mathrm{mmol} / \mathrm{l}]}\end{array}$ & $\begin{array}{c}8.2 \\
(2.05)\end{array}$ & $8.2-10.6$ \\
\hline $\begin{array}{l}\mathrm{Ca}_{\mathrm{c}}[\mathrm{mg} / \mathrm{dl}] \\
{[\mathrm{mmol} / \mathrm{ll}]}\end{array}$ & $\begin{array}{c}8.52 \\
(2.13)\end{array}$ & \\
\hline $\begin{array}{l}\mathrm{PO}_{4}{ }^{3-}[\mathrm{mg} / \mathrm{dl}] \\
{[\mathrm{mmol} / \mathrm{l}]}\end{array}$ & $\begin{array}{c}0.5 \\
(0.16)\end{array}$ & $1.0-2.5$ \\
\hline $\mathrm{Mg}^{+2}[\mathrm{mEq} / \mathrm{l}]$ & 2.0 & $1.3-2.1$ \\
\hline $\mathrm{Mg}_{\mathrm{c}}[\mathrm{mEq} / \mathrm{l}]$ & 2.2 & \\
\hline $\mathrm{Cl}^{-}[\mathrm{mEq} / \mathrm{l}]$ & 105 & $98-110$ \\
\hline $\begin{array}{l}\mathrm{UA}[\mathrm{mg} / \mathrm{dll}] \\
{[\mu \mathrm{mol} / \mathrm{l}]}\end{array}$ & $\begin{array}{c}1.7 \\
101\end{array}$ & $3.5-7.2$ \\
\hline $\begin{array}{l}\text { Glc }[\mathrm{mg} / \mathrm{dl}] \\
{[\mathrm{mmol} / \mathrm{ll}]}\end{array}$ & $\begin{array}{l}83 \\
4.6\end{array}$ & $70-100$ \\
\hline $\mathrm{AST}[\mathrm{U} / \mathrm{I}]$ & 124 & $7-21$ \\
\hline $\mathrm{ALT}[\mathrm{U} / \mathrm{I}]$ & 24 & $1-21$ \\
\hline$\gamma \mathrm{GT}[\mathrm{U} / \mathrm{I}]$ & 44 & $5-40$ \\
\hline $\mathrm{ALP}[\mathrm{U} / \mathrm{I}]$ & 80 & $32-110$ \\
\hline CK $[U / l]$ & 72 & $38-174$ \\
\hline Troponin I [ng/ml] & 0.1 & $<0.4$ \\
\hline $\mathrm{LDH}[\mathrm{U} / \mathrm{I}]$ & 420 & $50-150$ \\
\hline $\mathrm{FEPO}_{4}{ }^{3-}[\%]$ & 400 & $<20$ \\
\hline FEUA [\%] & 68 & $6-12$ \\
\hline $\mathrm{FEK}^{+}[\%]$ & 14 & $4-16$ \\
\hline $\mathrm{FENa}^{+}[\%]$ & 0.29 & - \\
\hline $\mathrm{e}-\mathrm{GFR}\left[\mathrm{ml} / \mathrm{min} / 1.73 \mathrm{~m}^{2}\right]$ & 65 & $>90$ \\
\hline $\begin{array}{l}\text { PTH }[\mathrm{pg} / \mathrm{ml}] \\
{[\mathrm{pmol} / \mathrm{l}]}\end{array}$ & $\begin{array}{c}52 \\
(5.5)\end{array}$ & $12-68$ \\
\hline
\end{tabular}

$B M I$ - body mass index, $T B I L$ - total bilirubin, $D B I L$ - direct bilirubin, Cre - creatinine, BUN - blood urea nitrogen, $\mathrm{K}^{+}$- potassium, $\mathrm{Na}^{+}$- sodium, $\mathrm{Ca}$ - total serum calcium, $\mathrm{Ca}$ - corrected calcium for albumin level, $\mathrm{PO}_{4}{ }^{3-}-$ phosphate, $\mathrm{Mg}^{+2}$ - total serum magnesium, $\mathrm{Mg}^{+2} \mathrm{c}$ - corrected magnesium for albumin level, $\mathrm{Cl}^{-}$- chloride, $U A$ - uric acid, Glc - glucose, AST - aspartate aminotransferase, ALT - alanine aminotransferase, $\gamma G T-\gamma$-glutamyl transferase, $A L P$ - alkaline phosphatase, $C K$ - creatinine kinase, $L D H$ - lactic dehydrogenase, FE - fractional excretion, e-GFR - estimated glomerular filtration rate, $\mathrm{PTH}$ - parathyroid hormone 
Though hypophosphataemia in this case was severe, there were no hypophosphataemia-related complications. The patient was administered oral phosphate $2000 \mathrm{mg}$ per day, with careful clinical monitoring. Serum phosphate levels reached $2.5 \mathrm{mg} / \mathrm{dl}(0.8 \mathrm{mmol} / \mathrm{l})$ in 4 days. Intravenous phosphate administration is required for symptomatic patients [1]. However, caution is needed since it can precipitate hypotension, severe hypocalcaemia and fatal arrhythmias [1].

No specific treatment for partial vein occlusion was given. He was discharged after 7 days.

\section{Discussion}

To our knowledge this is the lowest serum phosphate level reported in a cirrhotic patient. Hypophosphataemia is an electrolyte disorder mainly encountered in hospitalized and critically ill subjects [1]. In most of these cases, as also in our patient, hypophosphataemia is of multifactorial origin. Hypophosphataemia is causally related to a combination of transcellular shift of phosphate from the extracellular fluid into cells, excessive renal phosphate wasting and decreased intestinal phosphate absorption or poor dietary intake [1].

The marked hypophosphataemia observed in our patient was primarily the result of increased renal phosphate excretion, as evidenced by markedly increased phosphate fractional excretion (Table I).

Increased urinary excretion of phosphate is often associated with hyperparathyroidism, either primary or secondary [1]. However, in our patient serum parathyroid hormone (PTH) was within normal limits, while there was no hypercalcaemia (Table I). The patient was not examined with dual energy X-ray absorptiometry (DEXA) for osteoporosis evaluation.

Hypophosphataemia has been observed after administration of acetazolamide, thiazide diuretics as well as indapamide. On the other hand, loop diuretics and amiloride have minimal effects on phosphate metabolism [4].

Notably, hypophosphataemia in this case was accompanied by hypouricaemia, pointing to a proximal renal tubular defect. Indeed, renal urate fractional excretion was elevated. In addition, glycosuria was noted in a spot urine specimen, while serum glucose was within normal limits. Furthermore, urine $\beta_{2}$ microglobulin concentration, which is a reliable marker of proximal renal tubular dysfunction, was increased. It is worth mentioning that serum potassium levels were within normal limits in the presence of two diuretics (amiloride and furosemide) with opposite effects on renal potassium excretion (Table I).

The above findings indicate a rather generalized proximal tubular dysfunction. Fanconi's syndrome is the most common cause of renal phosphate wasting associated with glycosuria and hyperuricosuria [5]. Fanconi's syndrome is also associated with aminoaciduria and type 2 renal tubular acidosis [5]. However, our patient had mixed respiratory and metabolic alkalosis. Respiratory alkalosis was probably due to cirrhosis-associated hyperventilation. A superimposed metabolic alkalosis could be possibly due to effective circulating volume depletion, as evidenced by low sodium urinary excretion $\left(\mathrm{FENa}^{+}<1 \%\right)$ and increased urea nitrogen to creatinine ratio ( $>20$ ) owing to the presence of ascites and furosemide administration.

Acquired Fanconi's syndrome can be precipitated by a number of agents, such as anticancer drugs, antibiotics, antiviral agents and anticonvulsants [4]. In fact, antiviral agents used against chronic HBV infection such as adefovir, cidofovir and tenofovir have been implicated in this setting $[4,6]$. Our patient was receiving lamivudine, which has never been causally related to Fanconi's syndrome. Other well-known causes of Fanconi's syndrome (heavy metal exposure, hereditary disorders, dysproteinaemias and metabolic disorders) were ruled out.

In this case generalized proximal tubular damage seems to be causally related to jaundice. Fanconi's syndrome has been reported in jaundiced patients [3]. Furthermore, Bairaktari et al. (2001) showed that patients with obstructive jaundice had significantly lower uric acid and phosphate levels compared with age- and sex-matched controls [6]. However, in that study mean serum phosphate concentration was $3.0 \pm 0.6 \mathrm{mg} / \mathrm{dl}(0.96 \pm 0.19 \mathrm{mmol} / \mathrm{l})$, i.e. much greater compared with our case [7]. The underlying mechanisms are not fully elucidated. Bile acids may cause oxidative damage to tubular cell membranes, leading to the formation of oxygen free radicals [7-9]. Oxygen free radicals interfere with renal handling of electrolytes by inhibiting $\mathrm{Na}^{+}-\mathrm{H}^{+}$ antiport in tubular cells [8, 9].

Other factors may have also contributed to diminished phosphate levels in our case. Respiratory as well as metabolic alkalosis (both encountered in our patient) induce redistribution of phosphate from the extracellular compartment into the cells [1]. Additionally, in hepatic insufficiency 25 hydroxylation of vitamin $D$ in the liver may be impaired, thus leading to decreased synthesis of $1,25(\mathrm{OH})_{2} \mathrm{D}_{3}$ [1]. This may have contributed to hypophosphataemia via decreased phosphate intestinal absorption. Unfortunately, levels of $1,25(\mathrm{OH})_{2} \mathrm{D}_{3}$ were not measured in our patient.

Of special consideration, protein and calorie malnutrition, which is a common feature of chronic liver disease, constitutes a leading cause of hypophosphataemia. It should be noted that even though tubular dysfunction with impaired renal concentration of urine $\beta_{2}$ microglobulin has been reported in deeply jaundiced patients with 
hepatorenal syndrome, our patient did not manifest worsening azotemia or other signs of hepatorenal syndrome.

In conlusion, phosphate levels should be closely monitored in jaundiced patients, especially when other precipitating factors are present.

\section{References}

1. Bushinsky DA, Monk RD. Electrolyte quintet: calcium. Lancet 1998; 352: 306-11.

2. Magoula I, Tsapas G, Kountouras I, Paletas K. Cholangiocarcinoma and severe renal hypouricemia: a study of the renal mechanisms. Am J Kidney Dis 1991; 18: 514-9.

3. Liamis G, Bairaktari E, Elisaf M. Hypokalemia due to Fanconi syndrome in a patient with obstructive jaundice. Nephron 2002; 92: 711-2.

4. Liamis G, Milionis HJ, Elisaf M. Medication-induced hypophosphatemia: a review. QJM 2010; 103: 449-59.

5. Quigley R. Proximal renal tubular acidosis. J Nephrol 2006; 19 Suppl 9: S41-5.

6. Miltiadous G, Tsimihodimos V, Elisaf M. Salicylate-induced Fanconi-like syndrome. Arch Med Sci 2009; 5: 644-6.

7. Bairaktari E, Liamis G, Tsolas O, Elisaf M. Partially reversible renal tubular damage in patients with obstructive jaundice. Hepatology 2001; 33: 1365-9.

8. Sellinger M, Haag K, Burckhardt G, Gerok W, Knauf H. Sulfated bile acids inhibit $\mathrm{Na}(+)-\mathrm{H}+$ antiport in human kidney brush-border membrane vesicles. Am J Physiol 1990; 258: F986-91.

9. Bomzon A, Holt S, Moore K. Bile acids, oxidative stress, and renal function in biliary obstruction. Semin Nephrol 1997; 17: 549-62. 